\title{
ANALISIS PEMICU KASUS KEMATIAN MENDADAK DI TINJAU MENURUT ILMU BANTU HUKUM PIDANA
}

\author{
Kalista Rahma Salsabila*1, Muhammad Rusli Arafat,S.H.,M.H². \\ ${ }^{1}$,Mahasiswa, Universitas Singaperbangsa Karawang, Indonesia \\ ${ }^{2}$ Dosen, Universitas Singaperbangsa Karawang, Indonesia
}

e-mail: kalistarahmasalsabila@gmail.com, muhammadrusliarafat@gmail.com

\begin{abstract}
Abstrak
Pada penelitian ini membahas tentang analisis pemicu kasus kematian secara mendadak yang ditinjau melalui ilmu bantu hukum pidana yakni ilmu kedokteran forensic. Dalam peranan ilmu forensik ini dapat mempercepat penegak hukum untuk mengungkapkan suatu tindak pindana apakah seseorang yang mati mendadak itu karna pembunuhan, keracunan dan segala macam tindak pidana lainnya. Namun apabila seseorang wafat secara mendadak ini karna memang sudah kondisi tubuhnya maka dapat dikaji berdasarkan ilmu bantu seperti ilmu kedokteran ini. Mengenai ilmu bantu forensik ini meliputi ilmu biologi forensik, kimia forensik, fisika forensik, entomologi forensik, balistik, metalurgi forensik, toksikologi forensik, kriminalistik, odontologi forensik, antropologi forensik, psikiatri forensik, psikologi forensik, patofisologi forensik, dan digital forensik. Penggunaan metode penelitian ini menggunakan yuridis-normatif dengan mengolah data kualitatif yakni menggabungkan bahan-bahan hukum yang sama dengan penelitian ini lalu dibahas sehingga memperoleh kebenaran. Adapun kematian secara tiba-tiba kematian sepanjang 24 tersebut terjalin tandatanda yang dirasakan oleh korban sehingga terdapat sebagian pemicu yang dapat jadi alibi hendak terbentuknya kematian tiba- tiba tersebut antara lain merupakan hipertensi, kandas jantung dan lainnya.

Kata kunci-Kematian, mendadak, ilmu forensik
\end{abstract}

\section{PENDAHULUAN}

Kematian ialah suatu perihal yang tabu buat di bicarakan. Peristiwa kematian bukan cuma mengaitkan seorang yang wafat dunia tetapi juga berakibat untuk orang terdekat yang ditinggalkan. Tiap ada seseorang yang wafat hendak diiringi bersama terdapatnya seseorang yang ditinggalkan, buat tiap orang tua yang wafat hendak terdapat kanak- kanak yang di tinggal kan. Kematian yang dialami seseorang yang kita tahu terlebih yang sangat kita cintai, orang yang dikasihi, serta dekat dengan kita, hingga hendak terdapat masa dimana kita hendak meratapi kepergian mereka serta merasakan kesedihan yang mendalam, perihal tersebut hendak sangat berpengaruh terhadap kehidupan kita berikutnya. Kita pula sangat terasa tidak senang, serta kurang bisa menempuh kehidupan dengan baik.

Ketiadaan seorang sebab wafat secara tiba- tiba merupakan perubahan hidup yang memunculkan stress, bagi Holmes\&amp; Rahe( dilansir oleh Weiten dalam Yuliawati, 2007) serta

Al Qalam: Jurnal Ilmiah Keagamaan dan Kemasyarakatan Vol. 16, No. 1

$$
\text { Januari - Juni } 2022
$$


Kalista Rahma Salsabila, Muhammad Rusli Arafat : Analisis Pemicu Kematian Mendadak di Tinjau Menurut Ilmu Bantu Hukum Pidana

menuntut orang agar dapat beradaptasi terhadap penyesuaian. Ada sebagian reaksi terhadap tekanan pikiran bagi Weiten, 1997 wujud reaksi subyek terhadap stress ialah reaksi emosional berbentuk rasa duka( grief) serta reaksi sikap yang berupa sikap agresi( dalam Yuliawati, 2007). Tiap orang mempunyai respon yang tidak sama pada peristiwa kematian. Di fase dini orang yang ditinggalkan hendak merasa kaget, tidak yakin serta diam, kerap sedih ataupun gampang murka( Santrock 2004: 272).

Terlebih bila korban yang wafat itu terjalin seketika ataupun tidak di sangkasangka, dimana seebelumnya nampak sehat. Peristiwa yang demikian dalam ilmu medis forensik diucap " mati tibatiba'. Kematian tiba- tiba tidak selalu tidak diprediksi, serta kematian tiba- tiba yang tidak diprediksi tidak senantiasa menjadi tiba- tiba, tetapi kerap kali keduanya bisa terjalin secara bertepatan. Banyak permasalahan kematian yang bertabiat normal yang terbentuknya tidak bisa diramalkan tadinya, tiba- tiba ataupun ialah kematian tanpa terdapat yang memandang. Kematian tiba- tiba kerap terjalin serta didapatkan pada orang yang sebelumnya nampak dalam kondisi sehat( Apuranto\&amp; Mutahal, 2012).

Terlebih dahulu perlu diterangkan mengenai sekilas peninjauan tentang ilmu-ilmu forensic. ${ }^{1}$ Ilmu Kedokteran Kehakiman adalah delegasi berdasarkan ilmu kedokteran yang pelaksanaan ilmu kedokteran dalam penegakan keadilan. Ilmu kedokteran kehakiman ataupun ilmu kedokteran forensik (forensik science) ataupun umumnya disingkat IKK tidaklah bidang ilmu baru yang dipelajari oleh disiplin ilmu kedokteran ataupun disiplin ilmu hukum. Ilmu kedokteran ialah induk dari IKK yang dilaksanakan buat kepentingan penegakan hukum. Hukum pidana di Indonesia memastikan, atas bawah permintaan penyidik membagikan beban kewajiban untuk tiap dokter dalam kapasitasnya selaku pakar buat mengecek tiap orang yang cedera ataupun mati yang diprediksi selaku korban tindak pidana. Adapun mengecam sanksi pidana penjara sangat lama 4 bulan 2 pekan apabila dokter atas permintaan penyidik, menolak melaksanakan pengecekan medis forensic sesuai Pasal 216 berikutnya diucap KUH Pidana). ${ }^{2}$

Mengenai perubahan selanjutnya, nyatanya ilmu kedokteran forensik tak sekedar berguna ketika kegiatan penegakan hukum serta keadilan di lingkup bidang hukum, namun pula berguna dalam aspek kehidupan warga lain, contohnya menggulurkan bantuan saat penyelesaian klaim asuransi yang adil, baik untuk pihak yang diasuransi ataupun pihak yang mengasuransi, dalam menolong pemecahan permasalahan matematis, menolong usaha keamanan kerja saat bidang industri serta otomotif bersama penumpukan informasi korban musibah industri ataupun musibah

\footnotetext{
${ }^{1}$ R Soeparmono, Keterangan Ahli dan Visum Et Repertum dalam Aspek Hukum Acara Pidana, Semarang, Satya Wacana, Semarang, 1989.

${ }^{2}$ Erwin Asmadi, Ilmu Kedokteran Kehakiman, Medan, Pustaka Prima, 2019.
}

Al Qalam: Jurnal Ilmiah Keagamaan dan Kemasyarakatan Vol. 16, No. 1 Januari - Juni 2022 
Kalista Rahma Salsabila, Muhammad Rusli Arafat : Analisis Pemicu Kematian Mendadak di Tinjau Menurut Ilmu Bantu Hukum Pidana

lalu- lintas serta sebagainya. Buat bisa berikan dorongan yang optimal untuk pelbagai keperluan diatas, seseorang dokter dituntut buat bisa menggunakan ilmu medis yang dimilikinya secara maksimal. ${ }^{3}$

Adapun dalam penanganan suatu kasus, tak jarang sekali pihak penegak hokum seperti jaksa, polisi, hakim dan para penasehat hukum memperlukan pertolongan dari para ahli di bidang keilmuan masing-masing. Jika pertolongan tersebut mempunyai hubungannya dengan ilmu pengetahuan kedokteran, maka selayaknya yang dimintai pertolongan tersebut yakni seorang dokter. ${ }^{4}$ Dalam melaksanakan gunanya selaku dokter yang dimohon buat menolong dalam pengecekan medis forensik oleh penyidik, dokter memiliki tuntutan oleh peraturan perundangundang buat melaksanakannya dengan sukarela dan memakai bidang keilmuan secara patut. Dorongan yang harus diberikan oleh dokter apabila dimohon oleh penyidik antara lain merupakan melaksanakan pengecekan medis forensik atas seorang, baik terhadap korban hidup, korban mati ataupun terhadap komponen tubuh ataupun barang yang diprediksi berasal dari badan manusia. Apabila dokter lalai membagikan dorongan ini, hingga dia bisa diancam dengan pidana hukuman penjara.

Pada sesuatu masalah pidana yang memunculkan korban, dokter, diperlukan bisa menciptakan kelainan yang terjalin pada badan korban, bilamana kelainan tersebut mencuat, apa penyebabnya dan apa akibat yang mencuat terhadap kesehatan korban. Dalam perihal korban wafat, korban diharapkan bisa menarangkan pemicu kematian yang bersangkutan, gimana mekanisme terbentuknya kematian tersebut, dan menolong dalam ditaksir dikala kematian serta ditaksir metode kematian.

Buat kesemuanya itu, dalam bidang ilmu medis forensik dipelajari tatalaksana medikolegal, tanatologi, traumatologi, toksikologi, metode pengecekan serta seluruh suatu yang terpaut supaya seluruh dokter dalam penuhi kewajibannya menolong penyidik, bisa betul- betul menggunakan seluruh pengetahuan kedokterannya buat kepentingan peradilan dan kepentingan lain yang berguna untuk kehidupan bermasyarakat. ${ }^{5}$ Pada hal ini, para penegak hukum mempunyai fungsi serta tugas dalam melakukan pencarian bukti-bukti sah untuk dapat mengungkapkan suatu tindak pidana. ${ }^{6}$ Adapun tahap-tahap proses pemeriksaan tindak pidana yaitu penyidikan, penuntutan, dan persidangan.

\footnotetext{
${ }^{3}$ Arif Budiyanto, Ilmu Kedokteran Forensik, Jakarta, Fakultas Kedokteran Universitas Indonesia, 1997.

${ }^{4}$ Iwan Aflanie, Dkk. Ilmu Kedokteran Forensic dan Medikologi, Jakarta, PT. RajaGrafindo Persada, 2017.

${ }^{6}$ Helmi Romdhoni, Inews.co.id. https://www.inanews.co.id/2021/05/fungsi-dan-peran-ilmu-forensik-dalampenegakan-hukum-di-indonesia/ DIakses 5 Januari 2022 Pukul 12.00 WIB
}

Al Qalam: Jurnal Ilmiah Keagamaan dan Kemasyarakatan Vol. 16, No. 1 Januari - Juni 2022 
Kalista Rahma Salsabila, Muhammad Rusli Arafat : Analisis Pemicu Kematian Mendadak di Tinjau Menurut Ilmu Bantu Hukum Pidana

Tahapan yang penting dalam pengungkapan suatu tindak pidana yaitu pembuktian, karena proses tersebut akan menentukan seseorang bersalah atau bebas. Menurut Arthur jelas, pada Undang-Undang Nomor 14 Tahun 1970 Pasal 6 ayat (2) berbunyi. Tiada seorang juapun dapat dijatuhi pidana, kecuali apabila Pengadilan karena alat pembuktian yang sah menurut Undangundang, mendapat keyakinan, bahwa seseorang yang dianggap dapat bertanggung-jawab, telah bersalah atas perbuatan yang dituduhkan atas dirinya. Dalam pasal 183 KUHAP yang menyatakan bahwa hakim tidak boleh menjatuhkan pidana kepada seseorang kecuali apabila dengan sekurangkurangya dua alat bukti yang sah Ia mendapatkan keyakinan bahwa suatu tindak pidana benar-benar terjadi dan terdakwalah yang bersalah melakukannya.

Berdasarkan pasal 184 KUHAP ada 5 alat bukti yang sah di mata hukum yaitu, keterangan saksi, keterangan ahli, surat, petunjuk, dan keterangan terdakwa. Dijelaskan Arthur, proses pemeriksaan dalam mengungkap suatu tindak kejahatan membutuhkan pendekatan ilmiah. Adanya pendekatan ilmiah, penegak hukum tidak hanya bergantung pada keterangan saksi hidup atau tersangka dalam penyelidikan suatu tindak pidana. Contohnya, pendekatan ilmiah yaitu ilmu forensik. Ketika kita mendengar istilah forensik, yang terpikirkan pertama kali yaitu tentang bedah mayat, autopsi, kematian, dan lainnya. ${ }^{7}$

Selain itu, ilmu forensik terdiri dari ilmu biologi forensik, kimia forensik, fisika forensik, entomologi forensik, balistik, metalurgi forensik, toksikologi forensik, kriminalistik, odontologi forensik, antropologi forensik, psikiatri forensik, psikologi forensik, patofisologi forensik, dan digital forensik.

Secara umum ilmu forensik merupakan ilmu untuk melakukan pemeriksaan dan pengumpulan bukti-bukti fisik yang ditemukan di tempat kejadian perkara dan kemudian dihadirkan di dalam sidang pengadilan. Ilmu forensik sangat membantu aparat penegak hukum untuk mengungkapkan suatu tindak pidana yang terjadi mulai dari tingkat penyidikan sampai pada tahap pengadilan terhadap kasus yang berhubungan dengan tubuh atau jiwa manusia sehingga membuat terang suatu tindak pidana yang terjadi. Secara umum tahapan forensik yang biasa dilakukan meliputi pengumpulan (acquisition), perlindungan (preservation), analisa (analysis) dan presentasi (presentation). ${ }^{8}$

Ada pula dalam riset ini hendak memfokuskan pada permasalahan kematian tiba- tiba, kematian tiba- tiba merupakan sesuatu proses yang berhubungan terhadap waktu kematian yang mendadak pada sesuatu peristiwa ataupun kejadian. Kematian tiba- tiba bagi World Health Organization( World Health Organization) merupakan kematian yang terjalin pada 24 jam

\footnotetext{
${ }^{7}$ Ibid

${ }^{8}$ Ibid
}

Al Qalam: Jurnal Ilmiah Keagamaan dan Kemasyarakatan Vol. 16, No. 1 Januari - Juni 2022 
Kalista Rahma Salsabila, Muhammad Rusli Arafat : Analisis Pemicu Kematian Mendadak di Tinjau Menurut Ilmu Bantu Hukum Pidana

semenjak tanda- tanda mencuat. Dalam pemikiran ilmu medis forensik, tiap kematian tiba- tiba wajib diperlakukan selaku kematian yang tidak normal saat sebelum bisa dibuktikan secara ilmiah. Kematian tiba- tiba kerap disamakan dengan sudden alami unexpected death, ialah sesuatu kematian yang diakibatkan oleh sebab penyakit bukan akibat trauma ataupun keracunan. Kerapkali kematian dimengerti selaku penyelesaian dalam proses sekarat( denouement death) ataupun mati selaku penyelesaian. Kematian pula dimengerti selaku dini dari proses sekarat, ialah sesuatu titik yang tidak lagi. ${ }^{9}$

Di Indonesia sendiri telah banyak sekali kasus menimpa kematian tiba- tiba yang dirasakan seorang meliputi terdapatnya kasus kematian tiba- tiba di Gresik terus meningkat, yang sehingga dalam akhir aksi tersebut korban kehabisan nyawa. Sehingga dalam proses tersebut, hingga pihak penyidik hendak memohon dorongan ilmu kedokteran buat aktif berfungsi dalam penindakan permasalahan tersebut supaya mengenali penyebabnya. Buat itu, perihal tersebut mendesak penulis riset ini dengan judul“Analisis Pemicu Kasus Kematian Mendadak Di Tinjau Menurut Ilmu Bantu Hukum Pidana " ialah meliputi Ditaksir dikala kematian dan Penentuan karena kematian mendadak.

\section{METODE PENELITIAN}

Dalam riset ini penulis memakai tata cara riset yuridis- normatif. Tata cara pengolahan serta analisis informasi yang digunakan merupakan analisis kualitatif ialah informasi yang terkumpul dianalisis dengan metode mencampurkan bahan- bahan hukum itu dengan membuat klasifikasi terhadap bahan- bahan hukum tersebut, setelah itu informasi yang dianalisa secara yuridis kualitatif. Sehingga dalam menguraikan informasi yang menciptakan kejelasan permasalahan yang hendak dibahas serta buat menguak kebenaran yang terdapat.

\section{HASIL DAN PEMBAHASAN}

\section{Ditaksir dikala kematian}

Kematian merupakan sesuatu proses yang bisa diketahui secara klinis pada seseorang lewat pengamatan terhadap pergantian yang terjalin pada badan mayat. Pergantian itu hendak terjalin dari mulai terhentinya suplai oksigen. Definisi kematian tiba- tiba bagi World Health Organization merupakan kematian yang terjalin pada 24 jam semenjak tanda- tanda mencuat, tetapi pada kasuskasus forensik, sebagian besar kematian terjalin dalam hitungan menit ataupun apalagi detik semenjak indikasi pertama mencuat. Kematian tiba- tiba tidak senantiasa tidak terduga, serta

\footnotetext{
${ }^{9}$ Ahmad Yudianto, Ilmu Kedokteran Forensik, Surabaya, Scopindo, 2020.

Al Qalam: Jurnal Ilmiah Keagamaan dan Kemasyarakatan Vol. 16, No. 1 Januari - Juni 2022
} 
Kalista Rahma Salsabila, Muhammad Rusli Arafat : Analisis Pemicu Kematian Mendadak di Tinjau Menurut Ilmu Bantu Hukum Pidana

kematian yang tak diprediksi tidak senantiasa terjalin tiba- tiba, tetapi amat kerap keduanya terdapat bersamaan pada sesuatu permasalahan( Gresham, 1975). Kematian tiba- tiba bisa berbentuk :

1. Kematian mendadak( Instantaneous death)

Contoh: Seseorang yang dalam kondisi sehat bertamu ke rumah temannya, baru duduk sebagian menit setelah itu orang tersebut langsung wafat.

2. Kematian tidak terduga( Unexpected death)

Contoh: Seseorang yang cuma meringik sakit perut dikira gastritis biasa, sehingga dia bekerja semacam biasa, setelah itu orang tersebut langsung wafat di tempat kerja.

3. Kematian tanpa karena kematian yang tidak jelas( Unwitness death)

Contoh: Seseorang yang hidup sendiri tanpa sahabat di suatu rumah, setelah itu orang tersebut ditemui telah dalam kondisi meninggal dengan karena kematian tidak dikenal dengan jelas manifestasinya hendak bisa dilihat sehabis sebagian menit, jam, dan seterusnya. Sehabis sebagian waktu, mencuat pergantian pascamati yang jelas membolehkan penaksiran kematian lebih tentu( Simpson, 1985).

Sedangkan tiba- tiba ialah kata yang berkaitan dengan waktu yang kilat atau mendadak terhadap timbulnya sesuatu peristiwa ataupun kejadian. Tiba- tiba kaitannya dengan kematian bisa bertabiat absolut maupun relatif. Dilihat dari ekspedisi waktu kata tiba- tiba bisa dimaksud mendadak, dikala itu pula. Tiba- tiba juga bisa dialami untuk orang yang pernah berjumpa dengan korban dikala masih sehat serta sangat terkesan dengan pertemuan tersebut( Perdanakusuma, 1984).

Penafsiran mati tiba- tiba sesungguhnya berasal dari sudden unexpected natural death yang didalamnya tercantum kriteria pemicu ialah alami( alamiah, normal). Terminologi kematian tibatiba dibatasi pada sesuatu kematian alamiah yang terjalin tanpa diprediksi serta terjalin secara tibatiba, mensinonimkan kematian tiba- tiba dengan terminologi“" sudden alami unexpected death"( Hakim, 2010). Sebaliknya bagi Baradero( 2008), mati tiba- tiba mengandung penafsiran kematian yang tidak terduga, dalam kurun waktu kurang dari satu jam ataupun dalam waktu 2 puluh 4 jam. Kerap mati tiba- tiba terjalin dalam sebagian menit, sehingga tidak terdapat yang melihat ataupun tidak sempat menemukan pertolongan sama sekali Simpson( 1985) dalam bukunya“ Forensic Medicine".

Definisi dari mati tiba- tiba merupakan kematian terjalin tanpa diperkirakan tadinya, tanpa indikasi yang nyata tadinya ataupun gejalanya cuma dalam waktu yang pendek( menit ataupun jam), nontraumatis, tidak memiliki faktor kesengajaan( Chung, 1995) Pemicu mati tiba- tiba bisa di klasifikasikan bagi sistem badan, yaitu sistem lapisan saraf pusat, sistem kardiovaskular, sistem respirasi, system gastrointestinal, sistem haemopoietik serta sistem endokrin. Dari sistem- system

Al Qalam: Jurnal Ilmiah Keagamaan dan Kemasyarakatan Vol. 16, No. 1 Januari - Juni 2022 
Kalista Rahma Salsabila, Muhammad Rusli Arafat : Analisis Pemicu Kematian Mendadak di Tinjau Menurut Ilmu Bantu Hukum Pidana

ttersebut, yang sangat banyak jadi pemicu kematian merupakan system kardiovaskular, dalam perihal ini penyakit jantung( Perdanakusuma, 1984).

Kematian pada mendadak ini tidak cuma ialah permasalahan di dalam medis saja, hendak namun pula memiliki aspek sah. Seorang dinyatakan mati baik dilihat dari medis ataupun dari segi hukum apabila dokter atas bawah pengetahuan medis yang cocok dengan standar profesi tidak lagi menciptakan terdapatnya ciri kehidupan yang otomatis. Konsep mati serta berhentinya darah mengalir semacam dianut sepanjang ini serta pula diatur dalam PP. 18 tahun 1981 yang melaporkan kalau mati merupakan berhentinya guna jantung, paru paru, tidak dapat dipergunakan. Perihal ini diakibatkan sebab teknologi resusitasi sudah memungkinan jantung bisa dipacu buat berdenyut kembali serta paru- paru bisa dipompa buat kembang- kempis kembali. ${ }^{10}$

Meski isyarat kematian somatik telah nampak, saat sebelum terjalin kematian biologik masih bisa dicoba bermacam berbagai aksi semacam pemindahan organ badan buat transplantasi, kultur sel, jaringan serta organ ataupun jaringan badan orang tersebut masih bisa dipertahankan hidup terus meski terletak pada tempat yang berbeda sepanjang menemukan perawatan yang mencukupi. Kecenderungan dunia medis pada dikala ini menempatkan otak( dalam perihal ini batang otak) selaku kriteria yang sangat memastikan dalam perihal membenarkan terdapatnya kematian seorang, sebagaimana kriteria yang diajukan oleh Harvard Medical School, dimana salah satu uji yang terutama merupakan pengecekan kegiatan otak dengan elektroensefalografi( EEG).

Dengan demikian seorang hendak dinyatakan mati apabila pada pengecekan tidak ditemui terdapatnya kegiatan otak yang nampak dari hasil pengecekan EEG yang mendatar. Komentar lain berkata kalau tidak pada tempatnya bila dokter memutuskan kalau seseorang sudah mati meski EEG sudah meyakinkan perihal tersebut, namun masih nampak terdapatnya respirasi otomatis. Penentuan kematian tersebut amat berarti maksudnya apabila berhubungan dengan mungkin buat dikerjakannya aksi transplantasi. ${ }^{11}$

Dengan demikian kian susah seseorang ilmuwan kedokteran memastikan terbentuknya kematian pada manusia, apakah kematian somatik secara lengkap wajib nampak selaku ciri penentu terdapatnya kematian, ataupun lumayan apabila mengalami salah satu dari ciri kematian somatik, semacam kematian batang otak saja, henti napas saja, ataupun henti detak jantung saja telah bisa dipakai selaku patokan penentuan kematian manusia. Kasus penentuan kematian ini sangat berarti dalam pengambilan keputusan baik oleh dokter ataupun keluarganya.

\footnotetext{
${ }^{10}$ Eklesia A. Sendu, Johannis F. Mallo, Djemi Ch. Tomuka, Tinjauan Medikolegal Perkiraan Saat Kematian, Manado, Volume 5, Nomor 1, Suplemen, 2013.

11 Ibid
}

Al Qalam: Jurnal Ilmiah Keagamaan dan Kemasyarakatan Vol. 16, No. 1 Januari - Juni 2022 
Kalista Rahma Salsabila, Muhammad Rusli Arafat : Analisis Pemicu Kematian Mendadak di Tinjau Menurut Ilmu Bantu Hukum Pidana

Dalam peraturan perundang-undangan di Indonesia, batasan mati telah diangkat dalam peraturan pemerintah yaitu pada PP no. 18 Tahun 1981 tentang Bedah Mayat Klinis dan Bedah Mayat Anatomis serta transplantasi alat dan/atau jaringan tubuh manusia. Pada Bab 1 Pasal 1 tentang Ketentuan Umum Ayat g, dijelaskan bahwa :

"Meninggal dunia adalah insani yang diyakini oleh ahli kedokteran yang berwenang bahwa fungsi otak, pernapasan dan atau denyut jantung seseorang telah berhenti”.

Ayat g diatas mengenai definisi meninggal dunia kurang jelas; oleh karena itu IDI dalam seminar nasionalnya telah mencetuskan fatwa tentang masalah mati yang dituangkan dalam SK PB IDI No. 336/PB IDI/a.4 tertanggal 15 Maret 1988 yang disusul dengan SK PB IDI No. 231/PB.A.4/07/90.

Dalam fatwa tersebut dinyatakan kalau seorang dinyatakan mati apabila guna otomatis pernafasan serta jantung sudah menyudahi secara tentu ataupun ireversibel, ataupun fakta sudah terjalin kematian batang otak. Hukum tidak membagikan rumusan yang tegas menimpa kematian seorang, serta cuma mengatakan kalau kematian merupakan hilangnya nyawa seorang tanpa uraian lebih lanjut. Realitasnya, dengan kemajuan ilmu pengetahuan serta teknologi( iptek) medis masa saat ini detak jantung serta nafas seorang bisa terus dipertahankan sebab guna otonomnya dengan dorongan perlengkapan kedokteran tertentu meski sesungguhnya otak ataupun batang otak sudah menyudahi berperan.

Dengan terdapatnya perlengkapan respirator hingga disusunlah kriteria diagnostik baru buat kematian yang bersumber pada konsep brain death is death. Setelah itu dengan bermacam bawah pemikiran, konsep ini diperbaharui jadi brain stem death is death. Dunia cenderung menempatkan otak selaku kriteria yang sangat memastikan buat membenarkan terdapatnya kematian pada seorang lewat pengecekan kegiatan otak dengan elektroensefalograf( EEG). Seorang hendak dinyatakan mati apabila pada pengecekan tidak ditemui terdapatnya kegiatan otak sebagaimana dilihat dari hasil pengecekan EEG yang mendatar. Namun masih terdapat yang berkomentar tidak pada tempatnya diputuskan mati meski EEG sudah meyakinkan perihal tersebut, sebab masih nampak terdapatnya respirasi. Terdapatnya perubahan- perubahan yang terjalin sehabis kematian, yang bagi realitasnya mempunyai pola tertentu, membolehkan buat bisa memperkirakan kematian.

\section{Penentuan karena kematian mendadak}

Permasalahan kematian tiba- tiba yang penyebabnya penyakit pembuluh darah koroner ialah pemicu kematian paling banyak. Perihal ini disebabkan kedudukan bermacam aspek yang diprediksi turut mempengaruhi dalam meningkatnya permasalahan kematian tiba- tiba. Salah satunya merupakan perkembangan ekonomi yang menimbulkan pergantian pola mengkonsumsi

\section{Al Qalam: Jurnal Ilmiah Keagamaan dan Kemasyarakatan Vol. 16, No. 1}

$$
\text { Januari - Juni } 2022
$$


Kalista Rahma Salsabila, Muhammad Rusli Arafat : Analisis Pemicu Kematian Mendadak di Tinjau Menurut Ilmu Bantu Hukum Pidana

warga, ialah Kerutinan komsumsi santapan kilat saji yang berprotein besar serta berlemak, tanpa diiringi dengan mengkonsumsi santapan berserat. Pergantian tersebut berakibat dengan terbentuknya kenaikan penyakit pada pembuluh darah ialah aterosklerosis. Penyakit jantung serta pembuluh darah secara universal melanda pria lebih kerap dibandingkan wanita dengan perbandingan 7: 1 saat sebelum menopause, serta jadi 1: 1 sehabis wanita menopause.

Di Indonesia, semacam yang dilaporkan Tubuh Litbang Kementerian Kesehatan RI, persentase kematian akibat penyakit ini bertambah dari 5, 9\%(1975) jadi 9, 1\%(1981), 16, 0\%( 1986) serta 19, 0\%( 1995) Pada tahun- tahun terakhir ini, pemicu kematian tersering pada permasalahan kematian tiba- tiba merupakan penyakit kardiovaskular, sebaliknya pada sebagian dekade yang kemudian dilaporkan kalau pemicu kematian tersering merupakan penyakit peradangan saluran respirasi. ${ }^{12}$

Proses kematian umumnya diakibatkan oleh trauma( rudapaksa), asfiksia sebab bermacam berbagai pemicu asfiksia semacam asfiksia mekanik serta keracunan dan penyakit misalnya penyakit sistemik, degeneratif, kanker serta peradangan. Pada kematian tiba- tiba kardiovaskuler pemicu kematiannya merupakan penyakit ataupun kelainan kardiovaskuler itu sendiri. Dalam literatur mengatakan terdapat sebagian tata cara penentuan karena kematian antara lain lewat pengecekan eksternal postmortem( tiap hari diucap pengecekan luar), pengecekan internal( autopsi/ pengecekan dalam) serta pengecekan penunjang. Ilmu medis sudah membuat klasifikasi pemicu kematian ke dalam 4 jenis bersumber pada tipe penyakit/ patologi yang berhubungan dengan dampak yang ditimbulkan pada bermacam organ.

Jenis pemicu kematian ialah sesuatu jembatan tanatologis yang menghubungkan antara penyakit serta pemicu kematian ialah kematian jenis linear, jenis divergen, jenis konvergen serta jenis lingkungan. Pada kematian jenis linear, terdapat ikatan langsung antara pemicu kematian dengan penyakit dasarnya dengan kata lain kalau pemicu kematian seorang bisa didetetapkan dengan memandang kelainan organ tertentu yang mendasari misalnya pada seorang dengan riwayat penyakit jantung koroner( $\mathrm{PJK}$ ), ada sesuatu kondisi penebalan serta penyempitan arteri koronaria sehingga menimbulkan infark miokard serta lebih lanjut lagi memunculkan kematian oleh sebab mencuat kondisi komplikasi temponade pericardium. ${ }^{13}$

Pada kematian jenis divergen, tidak ada ikatan langsung antara pemicu kematian dengan penyakit dasarnya dengan kata lain seorang yang mempunyai penyakit kronis yang berat pada

\footnotetext{
${ }^{12}$ Dione S. M. Bhaskara, JohannisF.Mallo, DjemiTomuka, Hasil Autopsi Sebab Kematian Mendadak Tak Terduga Di Bagian Forensik BLU RSUP. Prof. DR.R.D.Kandou Manado Tahun 2010-2012,Manado, Vol 2, No 12014.

13 Taufik Suryadi, Penentuan Sebab Kematian Dalam Visum Et Repertum Pada Kasus Kardiovaskuler, Banda Aceh Jurnal Averrous. Vol.5 No.1 Mei 2019.
}

Al Qalam: Jurnal Ilmiah Keagamaan dan Kemasyarakatan Vol. 16, No. 1 Januari - Juni 2022 
Kalista Rahma Salsabila, Muhammad Rusli Arafat : Analisis Pemicu Kematian Mendadak di Tinjau Menurut Ilmu Bantu Hukum Pidana

sesuatu organ. Kematian yang ditimbulkan tidaklah secara langsung oleh sebab penyakit pada sesuatu organ tersebut namun sebab bermacam komplikasi non- organ yang ditimbulkan, contohnya seorang yang hadapi keganasan hendak mencuat indikasi sindrom lisis tumor, kakheksia, anemia, intoksikasi sehingga pada kesimpulannya wafat oleh sebab komplikasi non- organ tersebut.

Kematian jenis konvergen ialah jenis kematian yang diakibatkan bermacam kondisi patologi pada organ badan hendak menimbulkan kehancuran pada satu organ vital sehingga menimbulkan kematian pada seorang. Dengan kata lain, penyakit yang mendasari di bermacam sistem organ menimbulkan kematian lewat fase patogen akhir yang universal untuk penyakit yang mendasari tersebut, contohnya pada seorang dengan riwayat stenosing coronary sclerosis, ulkus gaster kronik yang diiringi perdarahan kesekian serta emfisema yang diiringi dengan bronkitis kronik wafat oleh sebab komplikasi bermacam kondisi tersebut memunculkan kondisi acute coronary insufisiensi.

Mengenai kematian jenis kompleks, kematian mencuat bagi sebab kelainan/ penyakit pada bermacam organ tubuh yang masing- masing nya memunculkan bermacam komplikasi yang silih bisa memunculkan kematian antara satu serta yang lain, contohnya seorang hendak bisa wafat oleh sebab hipertensi yang diiringi stenosis arteri basilaris serta emfisema yang diiringi bronkitis kronis. Kondisi tersebut masing- masingnya hendak memunculkan komplikasi berbentuk ensefalomalasia serta bronkial pneumonia yang masing- masingnya mempunyai kedudukan buat silih menimbulkan kematian pada seorang. ${ }^{14}$

Kematian tiba- tiba akibat kardiomiopati hipertrofi ialah perihal yang tidak sering. Kematian yang terjalin pada kardiomiopati hipertrofi akibat keadaan kandas jantung sehingga menimbulkan mati lemas. Oleh sebab itu diperlukan otopsi yang cermat serta pengecekan penunjang buat mendiagnosis dengan tentu. Ada 2 berbagai wujud kardiomiopati hipertrofik antara lain: hipertrofi yang simetris ataupun konsentris serta hipertrofi septal simetris dengan left ventricular outflow tract obstruction ataupun diucap pula idiopathichypertrophic subaortic stenosis( IHSS), ataupun hypertrophicobstructive outflow tract obstruction serta dengan ciri left ventricular outflow tract obstruction. Kendala irama kerap terjalin serta menimbulkan berdebar- debar, pusing hingga sinkop. Tekanan darah sistolik bisa pula menyusut, besarnya permasalahan kardiomiopati hipertrofik tidak bergejala/ asimptomatik. Penemuan post mortem antara lain: hipertrofi ventrikel dengan ataupun tanpa hipertrofi septal, pengerasan katup jantung, isyarat kandas jantung berbentuk ciri asfiksia. Pada pengecekan histopatologi didapatkan kehancuran, ekstrim hipertrofi, kepribadian miosit bercabang- cabang dengan fibrosis interstisial.

${ }^{14}$ Ibid

Al Qalam: Jurnal Ilmiah Keagamaan dan Kemasyarakatan Vol. 16, No. 1 Januari - Juni 2022 
Kalista Rahma Salsabila, Muhammad Rusli Arafat : Analisis Pemicu Kematian Mendadak di Tinjau Menurut Ilmu Bantu Hukum Pidana

Pada permasalahan ini tercantum dalam kematian tiba- tiba sebab semenjak onset indikasi hingga kematian terjalin berlangsung kurang dari 24 jam. 60-70\% pemicu kematian tiba- tiba paling banyak merupakan akibat penyakit kardiovaskular. Dari hasil otopsi didapatkan organ yang hadapi kelainan merupakan jantung berbentuk kardiomegali dengan LVH, pengerasan otot jantung serta katub jantung, rongga jantung kecil diiringi isyarat mati lemas pada organ lain. Oleh sebab itu mungkin besar pemicu kematiannya merupakan penyakit kardiovaskular. ${ }^{15}$

Pada pengecekan histopatologi membuktikan cerminan kardiomiopati. Kardiomiopati sendiri dibagi atas 3 ialah kardiomiopati hipertrofi, kardiomiopati dilatasi serta kardiomiopati restriktif. Perbandingan utama ketiga kardiomiopati terletak pada dimensi rongga jantung, ketebalan bilik miokardium, dan guna sistolik serta diastolik. Pada penderita yang telah wafat penemuan postmortem yang patognomonis merupakan dimensi rongga jantung dimana pada kardiomiopati hipertrofi cenderung kecil ataupun kecil sertamio kardium cenderung tebal( LVH). Cocok dengan penemuan otopsi serta histopatologis serta didukung dengan umur korban hingga sangat menunjang penaksiran tentu kematian merupakan kardiomiopati hipertrofi. Patogenesis sesuatu kardiomiopati hipertrofi bisa menimbulkan mati lemas ialah pada kardiomiopati terjalin mutase intra sarkomer yang tingkatkan kenaikan sensitivitas serta penciptaan Kalsium yang menyebabkan kenaikan kontraksi miokardium sehingga menimbulkan hipertrofi ventrikel kiri. Tidak hanya hal tersebut pula terjalin kenaikan sintesis kolagen yang menyebabkan terbentuknya fibrosis miokard yang menimbulkan hipertrofi ventrikel kiri. Terbentuknya hipertrofi ventrikel kiri jangka panjang hendak menimbulkan keadaan kandas jantung berbentuk aritmia ventrikel yang bisa menyebabkan asfiksia( mati lemas).

Penyakit di otot jantung yang bertabiat primer serta banyak di Indonesia merupakan kardiomiopati dilatasi ialah kelemahan otot jantung secara merata sehingga memunculkan sindrom kandas jantung yang menahun. Penyakit katup jantung akibat peradangan streptokokus hemolitikus tim A masih kerap didapatkan di wilayah perifer serta biasanya bermanifestasi selaku stenosis mitral. ${ }^{16}$

\section{KESIMPULAN}

Mati merupakan berhentinya guna jantung, paru paru, tidak dapat dipergunakan. Perihal ini diakibatkan sebab teknologi resusitasi sudah memungkinan jantung bisa dipacu buat berdenyut kembali serta paru- paru bisa dipompa buat kembang- kempis kembali. Ada pula yang namanya

\footnotetext{
${ }^{15}$ Raja Al Fath, Widyaiswara, Arif Rahman Sadad,Intarniati Nur Rohmah, Sigid Kirana Lintang Bhima, Kematian Mendadak Akibat Kardiomiopati Hipertrofi Pada Dewasa Muda, Semarang,Med Hosp. Vol 7, No. 2. 2020

${ }^{16}$ Rizka Maratus Sholihah, Mengatasi Aritmia Mencegah Kematian Mendadak, Depok, Vol. 5, No. 3, December 2017.
}

Al Qalam: Jurnal Ilmiah Keagamaan dan Kemasyarakatan Vol. 16, No. 1 Januari - Juni 2022 
Kalista Rahma Salsabila, Muhammad Rusli Arafat : Analisis Pemicu Kematian Mendadak di Tinjau Menurut Ilmu Bantu Hukum Pidana

mati tiba- tiba ialah kematian sepanjang 24 tersebut terjalin tanda- tanda yang dirasakan oleh korban sehingga terdapat sebagian pemicu yang dapat jadi alibi hendak terbentuknya kematian tiba- tiba tersebut antara lain merupakan hipertensi, kandas jantung, kehancuran pada satu organ vital, serta penyakit kronis yang lain.

\section{SARAN}

Penelitian ini perlu ditingkatkan dan disempurnakan lagi dalam mendorong pembaca mengetahui lebih lanjut tentang analisis penyebab kasus kematian mendadak ditinjau menurut kedokteran forensik.

\section{DAFTAR PUSTAKA}

Ahmad Yudianto, Ilmu Kedokteran Forensik, Surabaya, Scopindo, 2020.

Arif Budiyanto, Ilmu Kedokteran Forensik, Jakarta, Fakultas Kedokteran Universitas Indonesia, 1997.

Dione S. M. Bhaskara, JohannisF.Mallo, DjemiTomuka, Hasil Autopsi Sebab Kematian Mendadak Tak Terduga Di Bagian Forensik BLU RSUP. Prof. DR.R.D.Kandou Manado Tahun 2010-2012,Manado, Vol 2, No 12014.

Eklesia A. Sendu, Johannis F. Mallo, Djemi Ch. Tomuka, Tinjauan Medikolegal Perkiraan Saat Kematian, Manado, Volume 5, Nomor 1, Suplemen, 2013.

Erwin Asmadi, Ilmu Kedokteran Kehakiman, Medan, Pustaka Prima, 2019.

Helmi Romdhoni, Inews.co.id. https://www.inanews.co.id/2021/05/fungsi-dan-peranilmu-forensik-dalam-penegakan-hukum-di-indonesia/ DIakses 5 Januari 2022 Pukul 12.00 WIB

Iwan Aflanie, Dkk. Ilmu Kedokteran Forensic dan Medikologi, Jakarta, PT. RajaGrafindo Persada, 2017.

R Soeparmono, Keterangan Ahli dan Visum Et Repertum dalam Aspek Hukum Acara Pidana, Semarang, Satya Wacana, Semarang, 1989.

Raja Al Fath, Widyaiswara, Arif Rahman Sadad,Intarniati Nur Rohmah, Sigid Kirana Lintang Bhima, Kematian Mendadak Akibat Kardiomiopati Hipertrofi Pada Dewasa Muda, Semarang,Med Hosp. Vol 7, No. 2. 2020.

Taufik Suryadi, Penentuan Sebab Kematian Dalam Visum Et Repertum Pada Kasus Kardiovaskuler, Banda Aceh Jurnal Averrous. Vol.5 No.1 Mei 2019.

Al Qalam: Jurnal Ilmiah Keagamaan dan Kemasyarakatan Vol. 16, No. 1 Januari - Juni 2022 